\title{
Farklı Düzeylerdeki Vermikompost Uygulamasının Atdişi Mısırın (Zea mays L. indentata) Verim ve Verim Karakterlerine Etkisi
}

\author{
Muhammed Reşit ÖZEL ${ }^{1}$, Ayşe Gülgün ÖKTEM ${ }^{1 *}$ \\ ${ }^{1}$ Harran Üniversitesi Ziraat Fakültesi Tarla Bitkileri Bölümü, Şanlıurfa \\ (ORCID: 0000-0002-3573-0930) (ORCID: 0000-0002-7669-5801)
}

\begin{abstract}
Öz
$\mathrm{Bu}$ araştırma ile farklı düzeylerdeki vermikompost uygulamasının ikinci ürün olarak yetiştirilen atdişi (Zea mays L. indentata) mısırda verim ve verim karakterlerine etkisini belirlemek amaçlanmıştır. Araştırma tesadüf blokları deneme desenine göre 3 tekerrürlü olarak 2017 yılında Şanlıurfa'da yürütülmüştür. Denemede bitkisel materyal olarak Famoso hibrit mısır çeşidi kullanılmış̧ır. Vermikompost (VK) dozları O (kontrol), $250 \mathrm{~kg} \mathrm{da}^{-1} \mathrm{VK}, 500 \mathrm{~kg}$ $\mathrm{da}^{-1} \mathrm{VK}, 750 \mathrm{~kg} \mathrm{da}^{-1} \mathrm{VK}, 1000 \mathrm{~kg} \mathrm{da}^{-1} \mathrm{VK}, 1250 \mathrm{~kg} \mathrm{da}^{-1} \mathrm{VK}$ ve $1500 \mathrm{~kg} \mathrm{da}^{-1} \mathrm{VK}$ şeklinde oluşturulmuştur. Vermikompost dozları ekim öncesinde toprak yüzeyine serpilerek, karıştırılmıştır. Araştırma sonucunda, toprağa uygulanan farklı dozlardaki vermikompost uygulamalarının tepe püskülü çiçeklenme süresi ve sap kalınlığı hariç, bitki boyu, bitkide yaprak sayısı, bin tane ağırlığı, tane verimi, protein oranı, koçanda sıra sayısı ve tek koçan ağırlığı değerlerine etkisi istatistiki olarak önemli bulunmuştur. En yüksek tane verimi $\left(1561 \mathrm{~kg} \mathrm{da}^{-1}\right) 750 \mathrm{~kg} \mathrm{da}^{-1}$ vermikompost uygulamasından elde edilmiştir.
\end{abstract}

\section{The Effect of Vermicompost Application at Different Levels on Yield and Yield Characteristics in Dent Corn (Zea mays L. indendata)}

\begin{abstract}
This study, it was aimed to determine the effect of vermicompost application at different levels on yield and yield characteristics of dent corn plant (Zea mays L. indendata) as grown second crop conditions. The research was set up according to randomized complete block design with 3 replicates in 2017, Şanliurfa. Famoso hybrid corn variety was used as a plant material in the experiment. Vermicompost dosages (VK) were arranged as 0 (control), $250 \mathrm{~kg}$ $\mathrm{da}^{-1} \mathrm{VK}, 500 \mathrm{~kg} \mathrm{da}^{-1} \mathrm{VK}, 750 \mathrm{~kg} \mathrm{da}^{-1} \mathrm{VK}, 1000 \mathrm{~kg} \mathrm{da}^{-1} \mathrm{VK}, 1250 \mathrm{~kg} \mathrm{da}^{-1} \mathrm{VK}$ and $1500 \mathrm{~kg} \mathrm{da}^{-1} \mathrm{VK}$. Vermicompost dosages were pulverized to soil surface and mixed before sowing. As a result of the study, the effects of vermicompost applications at different doses applied to the soil on plant height, number of leaves per plant, thousand grain weight, grain yield, protein ratio, number of rows in the ear and ear weight values, excluding tassel flowering dates and stem diameter, were found statistically significant. The highest grain yield $\left(1561 \mathrm{ka} \mathrm{da}^{-1}\right)$ were obtained from $750 \mathrm{~kg} \mathrm{da}^{-1}$ of vermicompost application.
\end{abstract}

Keywords: Dent corn, grain yield, Sanliurfa, vermicompost.

\section{Giriş}

Dünya nüfusu sürekli olarak artmakta, artan nüfusun beslenmesi için de tarımsal üretimin arttırılmas1 gerekmektedir. Bu tarımsal ürünlerin en önemlilerinden birisi de mısır bitkisidir. Mısır, dünya tahıl ekiliş yönünden buğdaydan sonra ikinci sırada, üretim açısından baktığımızda ise ilk sırada yer alan önemli bir bitkidir [1]. Misırın, Dünya'daki ekim alanı 191.3 milyon ha $^{-1}$, misır üretimi ise 1.122 ( milyon ton),

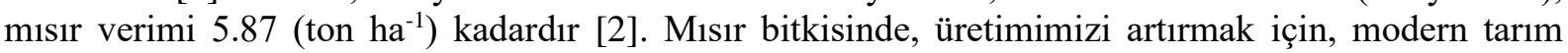

*Sorumlu yazar: gulgunoktem@harran.edu.tr

Geliş Tarihi: 12/05/2021, Kabul Tarihi: 29/06/2021 
teknikleri ile birlikte, çevreye zarar vermeyen, toprağı koruyan teknikleri de göz önüne almamız gerekmektedir.

Ülkemizde, toprakların $\% 75$ 'den fazla kısmında organik madde ve azot içeriği çok az veya az olarak saptanmıştır. Topraklarımızdaki yeterli ve/veya fazla organik madde içeriği ise yaklaşık \% 6 civarındadır. Topraklarda bitkilere yarayışı ı azot ve organik madde birbirleri ile yakından ilişkilidir [3]. $\mathrm{Bu}$ nedenle, topraklarımızdaki organik maddenin yetersizliğini ve besin elementleri eksikliğini gidermek için, çiftlik gübresi, yarasa gübresi, solucan gübresi gibi organik gübrelerin topraklara uygulanması önem arz etmektedir.

Son y1llarda Dünya'da bitkisel üretimde yaygın olarak kullanılan organik gübrelerden birisi de solucan gübresi olarak bilinen vermikomposttur. Topraktaki solucanlar, beslenmek için topraktaki mineralleri çözerek ortama bırakırlar. Bu atıklardan elde edilen solucan gübresi, içeriğinde simbiyotik bakteri (Rhizobium) ile asimbiyotik mikroorganizmalardan azot fiksasyonu yapan bakterinin (Azotobakter) yanında mikoriza mantarlarını da barındırır[4]. Vermikompost içerisinde yer alan yararlı mikroorganizmalar bitkinin kök bölgesine yerleşerek kökün etkileşim halinde bulunduğu rizosfere çeşitli antibiyotik, enzim (üreaz, fosfataz, $\beta$-glikosidaz vb.) ve bitki gelişim düzenleyiciler (oksin, sitokinin, giberellik asit vb.) salgılamaktadırlar [5]. Ayrıca organik olduğu için yabancı ot tohumu barındırmaz. Bitkilere karşı ters bir etki bulundurmaz ki, bunun en önemli nedeni doğal olmasıdır. Toprak pH'sı ve toprak yapısı gibi özelliklerin iyileştirmesini sağlar ve topraktaki yarayışlılık uzun süre devam etmektedir.

Değerli bir organik materyal olan solucan gübresinin, toprağın kimyasal, fiziksel ve biyolojik özelliklerine olumlu etkisinin olduğu, ayrıca vermikompostun uygulandığı birçok bitkide kalite ve verim artışı sağladığı açıklanmıştır $[6,7,8,9]$. Çıtak ve ark. [10], solucan gübresinin bitkinin gelişim ve toprak içeriğindeki verimliliğine etkileri incelemişler, verim, mineral madde kapsamı, bitki gelişimi gibi özelliklerin yanı sıra toprak verimliliği parametrelerinde de önemli artışlar sağladığını açıklamışlardır. Sap, saman, yaprak, sebze veya meyve gibi atıklarla beslenen solucanlardan elde edilen kompostun, toprak pH'sını düşürdüğünü, mısır bitkisinin kuru madde miktarını yükselttiği açıklanmıştır[11]. Jat ve Ahlawat [12], toprağa uygulanan $300 \mathrm{~kg} \mathrm{da}^{-1}$ vermikompostun, şeker misırda protein içeriği ve tane kuru ağırlığında artış sağladığını, ayrıca topraktaki alınabilir azot ve fosfor miktarına da olumlu etkide bulunduğunu açıklamıştır. Prasanna ve ark. [13], farklı besin kaynaklarının mısırda verim ve verim unsurlarına etkisini belirmek için yaptıkları çalışmada, kontrol, çiftlik gübresi, yeşil yaprak gübresi (pongamia), sorgum kalıntıları, kümes gübresi ve solucan gübresi kullanmışlardır. Araştırmacılar deneme sonucunda en yüksek kuru madde, bin dane ağırlığı, koçanda tane sayısı, tane verimi ve koçan verimi değerlerini, solucan gübre uygulamasından elde ettiklerini bildirmişlerdir.

Bu çalışmada; farklı seviyelerdeki vermikompostun, at dişi mısırın verim ve verim unsurlarına etkisini belirlemek, bunun yanı sıra tarımsal sürdürülebilirlik yönünden kimyasal gübreye alternatif olarak kullanılabilirliğini saptamak amaçlanmıştır.

\section{Materyal ve Metot}

Araştırma 2017 yılında Şanlıurfa Harran Ovası koşullarında ikinci ürün yetiştirme sezonunda yürütülmüştür. Deneme yerinin toprak yapısı killi ve $\mathrm{pH}$ oranı 7.2 olup alkali özelliktedir. Toprak organik maddelerce fakir, tuzluluk oranı önemsiz olup kireç oranı yüksektir. Araştırma alanının toprak özellikleri Tablo 1'de, iklim özellikleri ise Tablo 2'de verilmiştir.

Tablo 1. Deneme alanına ait toprak özellikleri

\begin{tabular}{cccccccccc}
\hline $\begin{array}{c}\text { Derin } \\
\text { lik } \\
(\mathrm{cm})\end{array}$ & $\begin{array}{c}\mathrm{HA} \\
\left(\mathrm{g} / \mathrm{cm}^{3}\right)\end{array}$ & $\begin{array}{c}\text { OM } \\
(\%)\end{array}$ & $\begin{array}{c}\text { Kum } \\
(\%)\end{array}$ & $\begin{array}{c}\text { Silt } \\
(\%)\end{array}$ & $\begin{array}{c}\text { Kireç } \\
(\%)\end{array}$ & $\mathrm{pH}$ & $\begin{array}{c}\mathrm{N} \\
\left(\mathrm{kg} \mathrm{ha}^{-1}\right)\end{array}$ & $\begin{array}{c}\mathrm{P}_{2} \mathrm{O}_{5} \\
\left(\mathrm{~kg} \mathrm{ha}^{-1}\right)\end{array}$ & $\begin{array}{c}\mathrm{K}_{2} \mathrm{O} \\
\left(\mathrm{kg} \mathrm{ha}^{-1}\right)\end{array}$ \\
\hline $0-30$ & 1,36 & 1,3 & 8 & 33 & 57 & 7.2 & 23 & 28 & 1283 \\
\hline
\end{tabular}

HA: hacim ağırlığı, OM: organik madde. 
Tablo 2. Araştırmanın yürütüldüğü döneme ait iklim verileri

\begin{tabular}{cccccc}
\hline Aylar & $\begin{array}{c}\text { Ortalama } \\
\text { Sicaklık }\left({ }^{\circ} \mathrm{C}\right)\end{array}$ & $\begin{array}{c}\text { En Yüksek } \\
\text { Sicaklık }\left({ }^{\circ} \mathrm{C}\right)\end{array}$ & $\begin{array}{c}\text { En Düşük } \\
\text { Sicaklık }\left({ }^{\circ} \mathrm{C}\right)\end{array}$ & $\begin{array}{c}\text { Ortalama Nispi } \\
\text { Nem }(\%)\end{array}$ & Yağ Ş̧ $(\mathrm{mm})$ \\
\hline Haziran & 29.6 & 36.4 & 17.5 & 27.8 & 0.0 \\
Temmuz & 34,2 & 41.3 & 22,4 & 23.7 & 0.0 \\
Ağustos & 32.2 & 39.4 & 21.4 & 35.8 & 0.0 \\
Eylül & 29.6 & 36.9 & 18.3 & 28.7 & 0.0 \\
Ekim & 20.6 & 27.4 & 11.3 & 35.7 & 15.7 \\
Kasım & 13.4 & 19.1 & 2.5 & 55.9 & 16.3 \\
\hline
\end{tabular}

Kaynak: Anonim [14].

Çalışmada bitkisel materyal olarak 115 günlük gelişme periyoduna sahip Famoso at dişi mısır çeşidi kullanılmıştır. Denemede organik materyal olarak kullanılan vermikompostun bazı özellikleri Tablo'3’te verilmiştir.

Tablo 3. Araştırmada kullanılan solucan gübresine (vermikompost) ait bazı analiz değerleri

\begin{tabular}{|c|c|c|c|c|c|c|c|}
\hline $\begin{array}{c}\text { Analiz } \\
\text { Değerleri }\end{array}$ & $\begin{array}{c}\mathrm{pH} \\
\mathrm{dS} / \mathrm{m}\end{array}$ & $\begin{array}{c}\text { Toplam } \\
\text { Azot } \\
\%\end{array}$ & $\begin{array}{c}\text { Toplam } \\
\text { Fosfor } \\
\text { Pentaoksit } \\
\%\end{array}$ & $\begin{array}{c}\text { Suda } \\
\text { Çözünür } \\
\text { Potasyum } \\
\text { Oksit \% }\end{array}$ & $\begin{array}{l}\text { Suda Çözünür } \\
\text { Kalsiyum } \\
\text { Oksit\% }\end{array}$ & $\begin{array}{c}\text { Toplam } \\
\text { Humik+Fulvik } \\
\text { asit } \%\end{array}$ & $\begin{array}{c}\text { Nem } \\
\%\end{array}$ \\
\hline Sonuçlar & 7.27 & 3.24 & 3.28 & 1.24 & 0.10 & 41.46 & 48 \\
\hline
\end{tabular}

Vermikompost dozları 1.uygulama: kontrol (vermikompost verilmemiş, $17 \mathrm{~kg} \mathrm{da}^{-1} \mathrm{~N}$ ve $8 \mathrm{~kg} \mathrm{da}^{-}$ ${ }^{1} \mathrm{P}$ verilmiştir), 2. uygulama: $250 \mathrm{~kg} \mathrm{da}^{-1} \mathrm{VK}$, 3.uygulama: $500 \mathrm{~kg} \mathrm{da}^{-1} \mathrm{VK}$, 4.uygulama: $750 \mathrm{~kg} \mathrm{da}^{-1}$ VK, 5.uygulama: $1000 \mathrm{~kg} \mathrm{da}^{-1} \mathrm{VK}$, 6.uygulama: $1250 \mathrm{~kg} \mathrm{da}^{-1} \mathrm{VK}$, 7.uygulama: $1500 \mathrm{~kg} \mathrm{da}^{-1} \mathrm{VK}$ olacak şekilde düzenlenmiştir. Vermikompost dozları belirlenen miktarlarda tartılarak ekimden önce toprağa karıştırılmış, akabinde ekim işlemi gerçekleştirilmiştir.

Ekimden önce, buğday hasadından sonra toprak pullukla derin sürülmüş, kültivatör ve goble-disk ardından tapan çekilerek düzlenmiş ve ekime hazır hale getirilmiştir. Araştırma tesadüf blokları deneme desenine göre 07.07.2017 tarihinde üç tekrarlamalı olarak kurulmuştur. Denemede sıra araları $70 \mathrm{~cm}$, sıra üzeri ise $18 \mathrm{~cm}$ 'den ve her parsel 4 sıradan oluşturulmuş, parsel boyu $5 \mathrm{~m}$ olarak alınmıştır. Ekimden yaklaşık 1 hafta sonra bitki çıkışı gözlenmiştir.

Ekimden sonra iyi bir çıkışın sağlanması için yağmurlama sulama sistemiyle tav sulaması yapılmıştır. Çıkış sağladıktan sonra 6-7 gün ara ile bitki ve toprağın su isteğine göre her parsele kendi içerisinde karıklar yardımıyla eşit miktarda su verilmiştir ve bitki gelişimi kontrol edilmiş̧ir. İlk çapalama bitki boyu $15-20 \mathrm{~cm}$ iken el çapası şeklinde, ikinci çapalama işlemi ise bitkiler $40-45 \mathrm{~cm}$ iken traktör çapası ile birlikte boğaz doldurma yapılmıştır. Deneme alanındaki yabancı ot durumuna göre gerektiğinde her sulamadan sonra deneme alanı elle temizlenerek yabanc1 ot kontrolü gerçekleştirilmiştir. Hasat bitkilerin fizyolojik gelişimine göre belirlenerek elle yapılmıştır. Bitkisel ve koçan özellikleri her parsel içerisinden rastgele seçilen 10 mısır bitkisi ve koçanının örneğinde belirlenmiştir. Hasat, her bir parselin orta sıralarında bulunan mısır bitkilerinin koçanlarının toplanmasıyla yapılmıştır. Hasat döneminde ise tanedeki nem oranı Dickey John nem ölçer ile belirlenerek, tane verimi $\% 15^{\prime} \mathrm{e}$ göre düzeltilmiştir. Tanedeki protein oranı Kjeldahl auto analyzer cihazı ile 15 gr numune ile ICC Standart No. 167'ye göre belirlenmiştir.

Deneme sonucu elde edilmiş veriler kullanılarak varyans analizi yapılmış, ortalamalar ise LSD testine göre gruplandırılmıştır.

\section{Bulgular ve Tartışma}

\subsection{Tepe Püskülü Çiçeklenme Süresi (gün)}

Yapılan varyans analiz sonucuna göre vermikompost uygulamalarının tepe püskülü çiçeklenme süresi üzerine etkisi istatistiki olarak önemsiz bulunmuştur. Tepe püskülü çiçeklenme süresi 54.66 ile 53.33 gün arasında değişim göstermiştir (Tablo 4). Deneme ortalaması ise 54.14 gün olarak gerçekleşmiştir. Tepe püskülü çiçeklenme süresi çevre koşulları ve genotipe bağlı bir özellik olmakla birlikte, vermikompost uygulamaları tepe püskülü çiçeklenme süresine olumlu veya olumsuz herhangi bir etkide 
bulunmamıştır. Tepe püskülü çiçeklenme süresini mısır bitkisinde, İdikut ve Kaya [15], 46.00 ile 57.00 gün, Öktem ve Toprak [16], 47.3-51.7 gün, Erdal ve ark. [17], 59-66 gün arasında bulmuşlardır. Bulgularımız araştırıcıların bulguları ile benzerlik göstermektedir.

\subsection{Sap Kalınlığı (mm)}

Bitkide sap kalınlığı bakımından yapılan varyans analiz sonucuna göre uygulamalar arasında istatistiki olarak önemli farklılık bulunmamıştır. Sap kalınlığı değeri $22.12 \mathrm{~mm}$ ile $24.00 \mathrm{~mm}$ arasında değişim göstermiştir (Tablo 4). Sap kalınlığı değeri genotipik bir özellik olmakla birlikte, yetiştirme koşullarından da etkilenmektedir. Çalışmada vermikompost uygulamalarının bitkide sap kalınlığına olumlu veya olumsuz etkisi gözlenmemiştir. Çeşitli araştırıcılar mısırda yaptıkları çalışmalarda sap kalınlığı değerini Üzen [18], $18.64 \mathrm{~mm}$ ile $14.18 \mathrm{~mm}$ arasında bulgularımızdan daha düșük bulurken, Bakış [19], 28.6-31.4 cm daha yüksek değerler bulmuştur. Ancak, bulgularımız İdikut ve Kara [15] 25$21 \mathrm{~mm}$, Demirbay ve Kılıç [20], 24.8-28.3 cm bulguları ile uyum içindedir.

\subsection{Koçanda Sıra Sayısı (sıra/koçan)}

Yapılan varyans analiz sonucuna göre, koçanda sıra sayısı bakımından vermikompost uygulamaları arasında 0.01 önem seviyesinde istatistiki olarak farklılık belirlenmiştir. En yüksek koçanda sıra sayısını $15.86 \mathrm{sıra} / \mathrm{koçan} \mathrm{ile} 750$ ve $1500 \mathrm{~kg} / \mathrm{da}$ vermikompost uygulaması vermiş, ancak $500 \mathrm{~kg} / \mathrm{da} \mathrm{VK}, 750 \mathrm{~kg}$ $\mathrm{da}^{-1} \mathrm{VK}, 1250 \mathrm{~kg} \mathrm{da}^{-1} \mathrm{VK}$ ve $1500 \mathrm{~kg} \mathrm{da}^{-1} \mathrm{VK}$ aynı istatistiki grupta yer almıştır. Babaoğlu [21], koçandaki sıra sayısının fazla olmasının daha fazla tane demek olduğunu, bunun da tane verimini olumlu etkileyeceğini bildirmiştir. Prasanna ve ark. [13], değişik organik gübre uygulamaları sonucunda en yüksek koçanda tane sayısını solucan gübresi uygulamalarının verdiğini bildirmişlerdir. Araştırmada, vermikompost uygulamaları koçanda sıra sayısını artırıcı etkide bulunmuştur.

Şekeroğlu ve ark. [22], Vartanlı [23], koçanda sıra sayısı değerleri bakımından bulgularımıza benzer sonuçlar elde ederken, Yılmaz ve Han[24], daha yüksek sonuçlar elde etmişlerdir.

Tablo 4. Farklı dozlarda Vermikompost uygulamalarının tepe püskülü çiçeklenme süresi, sap kalınlığı ve koçanda sıra sayısına ait ortalama değerleri ve oluşan istatistiki gruplar

\begin{tabular}{|c|c|c|c|}
\hline $\begin{array}{l}\text { Vermikompost }(\mathrm{VK}) \\
\text { Miktarları }\left(\mathrm{kg} \mathrm{da}^{-1}\right)\end{array}$ & $\begin{array}{l}\text { Tepe Püskülü } \\
\text { Çiçeklenme } \\
\text { Süresi (gün) }\end{array}$ & Sap Kalınlığı (mm) & $\begin{array}{c}\text { Koçanda Sıra Sayısı } \\
\text { (sıra/koçan)** }\end{array}$ \\
\hline Kontrol & $54.66 \dagger$ & 24.00 & $15.00 \mathrm{~b}$ \\
\hline $250 \mathrm{~kg} \mathrm{da}^{-1} \mathrm{VK}$ & 54.33 & 23.72 & $15.06 \mathrm{~b}$ \\
\hline $500 \mathrm{~kg} \mathrm{da}^{-1} \mathrm{VK}$ & 54.00 & 23.75 & $15.66 \mathrm{a}$ \\
\hline $750 \mathrm{~kg} \mathrm{da}^{-1} \mathrm{VK}$ & 54.33 & 22.28 & $15.86 \mathrm{a}$ \\
\hline $1000 \mathrm{~kg} \mathrm{da}^{-1} \mathrm{VK}$ & 55.33 & 23.33 & $15.70 \mathrm{a}$ \\
\hline $1250 \mathrm{~kg} \mathrm{da}^{-1} \mathrm{VK}$ & 54.00 & 22.12 & $15.60 \mathrm{a}$ \\
\hline $1500 \mathrm{~kg} \mathrm{da}^{-1} \mathrm{VK}$ & 53.33 & 23.46 & $15.86 \mathrm{a}$ \\
\hline LSD & - & - & 0.41 \\
\hline Ortalama & 54.14 & 23.24 & 15.53 \\
\hline
\end{tabular}

**: \%1'e göre önemli *: \%5'e göre önemli

$\dagger$ : Aynı harf grubunda yer alan ortalamalar arasında LSD testine göre 0.05 düzeyde istatistikî olarak önemli farkl1lik yoktur

\subsection{Bitki Boyu (cm)}

Farklı miktarlarda vermikompost uygulamasının atdişi mısır çeşidinde bitki boyuna ait yapılan varyans analiz sonucuna göre uygulamalar arasında istatistiki olarak \%1 seviyesinde önemli farklılık tespit edilmiştir (Tablo 5). Araştırmada bitki boyu değerleri $209.90 \mathrm{~cm}$ ile $219.90 \mathrm{~cm}$ arasında değişmiştir. En yüksek bitki boyu değeri $1000 \mathrm{~kg} \mathrm{da}^{-1}$ vermikompost dozunda $219.90 \mathrm{~cm}$ olarak bulunurken, en düşük bitki boyu kontrol uygulamasından $209.90 \mathrm{~cm}$ olarak elde edilmiştir.

Vermikompost içeriğinde bulunan organik madde, humik ve fulvik asit, besin elementi içeriği nedeniyle, misırda bitki boyunu artırıcı etkide bulunmuş olabilir. Turgut [25], bitki boyunun tane verimi üzerine olumlu etkisinin olduğunu bildirmiştir. Bitki boyunun vermikompost uygulaması ile arttığı, 
bunun tane verimini de olumlu etkilemiş olabileceği düşünülebilir. Çeşitli araştırıcılar vermikompost miktarı arttıkça bitki boyunun da arttı̆̆ını, solucan gübresinin bitki boyu üzerine olumlu etkide bulunduğunu bildirmişlerdir [26,27,28,29,30]. Bulgularımız araştırıcıların bu tespitlerini destekler niteliktedir.

Tablo 5. Farklı dozlarda Vermikompost uygulamalarının bitki boyu, bitkide yaprak sayısı ve bin tane ağırlı̆̆ ortalama değerleri ve oluşan istatistiki gruplar

\begin{tabular}{cccc}
\hline $\begin{array}{c}\text { Vermikompost }(\mathrm{VK}) \\
\text { Miktarları }\left(\mathrm{kg} \mathrm{da}^{-1}\right)\end{array}$ & Bitki boyu $(\mathrm{cm})^{* *}$ & $\begin{array}{c}\text { Yaprak sayısı } \\
(\text { adet/bitki })^{*}\end{array}$ & $\begin{array}{c}\text { Bin Tane Ağırlığ } \\
(\mathrm{g}) * *\end{array}$ \\
\hline $\begin{array}{c}\text { Kontrol } \\
250 \mathrm{~kg} \mathrm{da}^{-1} \mathrm{VK}\end{array}$ & $209.90 \mathrm{e} \dagger$ & $12.20 \mathrm{~b} \mathrm{c}$ & $312.81 \mathrm{c}$ \\
$500 \mathrm{~kg} \mathrm{da}^{-1} \mathrm{VK}$ & $219.10 \mathrm{ab}$ & $12.03 \mathrm{c}$ & $340.19 \mathrm{~b}$ \\
$750 \mathrm{~kg} \mathrm{da}^{-1} \mathrm{VK}$ & $214.63 \mathrm{bcd}$ & $12.80 \mathrm{a} \mathrm{b}$ & $351.67 \mathrm{ab}$ \\
$1000 \mathrm{~kg} \mathrm{da}^{-1} \mathrm{VK}$ & $211.90 \mathrm{de}$ & $12.83 \mathrm{a}$ & $359.98 \mathrm{a}$ \\
$1250 \mathrm{~kg} \mathrm{da}^{-1} \mathrm{VK}$ & $219.90 \mathrm{a}$ & $12.80 \mathrm{a} \mathrm{b}$ & $353.46 \mathrm{ab}$ \\
$1500 \mathrm{~kg} \mathrm{da}^{-1} \mathrm{VK}$ & $214.26 \mathrm{cde}$ & $12.90 \mathrm{a}$ & $353.11 \mathrm{ab}$ \\
LSD & $217.36 \mathrm{abc}$ & $12.86 \mathrm{a}$ & $353.32 \mathrm{ab}$ \\
\hline Ortalama & 4.59 & 0.61 & 14.32 \\
\hline
\end{tabular}

**: \%1'e göre önemli *:\%5'e göre önemli

$\dagger$ : Aynı harf grubunda yer alan ortalamalar arasında LSD testine göre 0.05 düzeyde istatistikî olarak önemli farklilik yoktur.

\subsection{Yaprak Sayısı (adet/bitki)}

Yaprak sayısı bakımından yapılan varyans analiz sonucuna göre vermikompost uygulamaları arasında istatistiki olarak \%5 önem seviyesinde farklılık saptanmıştır (Tablo 5). Yaprak sayısı en yüksek 1250 $\mathrm{kg} \mathrm{da}^{-1}$ vermikompost dozunda 12.90 adet/bitki bulunurken, yaprak sayısı en düşük $250 \mathrm{~kg} \mathrm{da}^{-1} \mathrm{VK}$ uygulamasından 12.03 adet/ bitki olarak belirlenmiştir.

Çalışmayı destekler nitelikte Özkan ve Müftüoğlu [31], vermikompostun yaprak sayısı üzerinde istatistiki olarak önemli bir artış sağladığını belirtmiş, Durukan [32], ise mısır bitkisine vermikompost uygulandığında, bitkinin toprak üstü aksamının arttırdığını ve bu artışın \%40 oranında olduğunu açıklamıştır. Müftüoğlu ve arkadaşları [26], Köksal ve ark. [33] ise vermikompost uygulamasının yaprak sayısını arttırdığını, ancak bu artışların istatistiki olarak önemli bulunmadığını belirtmişlerdir.

\subsection{Bin tane ağırlığı (g)}

Yapılan varyans analiz sonucuna göre vermikompost uygulamaları arasında bin tane ağırlığı bakımından $\% 1$ düzeyinde istatistiki olarak önemli fark bulunmuştur. Bin tane ağılığı en yüksek $750 \mathrm{~kg} \mathrm{da}{ }^{-1}$ vermikompost uygulamasında, $359.98 \mathrm{~g}$ olarak bulunurken, bin tane ağırlı̆̆ 1 en düşük kontrol parselinden $312.81 \mathrm{~g}$ olarak bulunmuştur. Bin tane ağırlı̆̆ çeşidin genetik yapısına bağlı bir özellik olmakla birlikte, yetiştirme koşullarından da etkilenmektedir. Araştırmada vermikompost uygulamaları bin tane ağırlığına olumlu etkide bulunmuştur. Farklı organik gübre uygulamalarının sonucunda en yüksek bin tane ağırlıklarının solucan gübresi uygulamalarından elde edildiği açıklanmıştır [13].

\subsection{Koçanda tane ağırlığı (g/koçan)}

Yapılan varyans analiz sonucuna göre vermikompost uygulamalarının koçanda tane ağırlı̆̆ üzerine \%1 önem düzeyinde istatistiki olarak önemli fark saptanmıştır. En yüksek koçanda tane ağırlığı değeri 750 $\mathrm{kg} \mathrm{da}^{-1}$ vermikompost uygulamasından $(293.1 \mathrm{~g})$, elde edilirken, en düşük koçanda tane ağırlı̆̆ 1 ise kontrol parselinden (254.0 g) elde edilmiştir (Tablo 6). Koçanda tane ağırlığı değeri tane verimine doğrudan etki eden özelliklerden birisidir. Koçanda tane ağırlığının yüksek oluşu birim alandaki tane veriminin de artmasını ifade etmektedir. Ayrıca, tek koçan ağırlığı değeri bir çeşit özelliği olmakla birlikte, yetiştirme koşullarından da etkilenmektedir. Vermikompost uygulamaları sonucu bitkinin ihtiyaç duyduğu besin maddeleri toprakta elverişli bir biçimde bulunmakta ve bitki tarafından alımı da artmaktadır [34]. Benzer şekilde, bu çalışmada da vermikompost uygulamaları ile bitkinin besin elementi alımının arttığı, dolayısıyla koçanda tane ağırlığına da olumlu etkide bulunduğu 
düşünülmektedir. Tek koçan ağırlığı bakımından, bulgularımıza benzer sonuçlar, Şanlıurfa koşullarında Taş [35], 225.70-279g arasında, Aygün[36], Bursa koşullarında 214.48-272.37g, İdikut ve Kara[15] ise Kahramanmaraş koşullarında 177- 293g tarafından bildirilmiştir. Kuşvuran ve Nazlı [37], ise 159$211 \mathrm{~g}$ arasındaki değerlerle bulgularımızdan daha düşük sonuçlar elde etmişlerdir.

Tablo 6. Farklı dozlarda Vermikompost uygulamalarının koçanda tane ağırlığı, protein oranı ve tane verimi ortalama değerleri ve oluşan gruplar

\begin{tabular}{cccc}
\hline $\begin{array}{c}\text { Vermikompost }(\mathrm{VK}) \\
\text { Miktarları }\left(\mathrm{kg} \mathrm{da}^{-1}\right)\end{array}$ & $\begin{array}{c}\text { Koçanda Tane } \\
\text { Ağırlı̆ } 1(\mathrm{~g} / \mathrm{koçan}))^{* *}\end{array}$ & $\begin{array}{c}\text { Protein Oranı } \\
(\%) * *\end{array}$ & $\begin{array}{c}\text { Tane Verimi } \\
\left(\mathrm{kg} \mathrm{da}^{-1}\right)^{* *}\end{array}$ \\
\hline Kontrol & $254.00 \mathrm{c}$ & $7.38 \mathrm{c} \dagger$ & $1193.11 \mathrm{~b}$ \\
$250 \mathrm{~kg} \mathrm{da}^{-1} \mathrm{VK}$ & $274.63 \mathrm{~b}$ & $7.40 \mathrm{c}$ & $1341.28 \mathrm{~b}$ \\
$500 \mathrm{~kg} \mathrm{da}^{-1} \mathrm{VK}$ & $285.43 \mathrm{a} \mathrm{b}$ & $7.48 \mathrm{bc}$ & $1375.66 \mathrm{ab}$ \\
$750 \mathrm{~kg} \mathrm{da}^{-1} \mathrm{VK}$ & $293.10 \mathrm{a}$ & $7.74 \mathrm{ab}$ & $1561.26 \mathrm{a}$ \\
$1000 \mathrm{~kg} \mathrm{da}^{-1} \mathrm{VK}$ & $287.90 \mathrm{a} \mathrm{b}$ & $7.74 \mathrm{ab}$ & $1560.10 \mathrm{a}$ \\
$1250 \mathrm{~kg} \mathrm{da}^{-1} \mathrm{VK}$ & $286.90 \mathrm{a} \mathrm{b}$ & $7.75 \mathrm{ab}$ & $1560.45 \mathrm{a}$ \\
$1500 \mathrm{~kg} \mathrm{da}^{-1} \mathrm{VK}$ & $286.06 \mathrm{a} \mathrm{b}$ & $8.00 \mathrm{a}$ & $1560.90 \mathrm{a}$ \\
LSD & 16.0 & 3.01 & 39.1 \\
Ortalama & 281.14 & 7.64 & 1450.39 \\
\hline
\end{tabular}

**: \%1'e göre önemli *:\%5'e göre önemli

$\dagger$ : Aynı harf grubunda yer alan ortalamalar arasında LSD testine göre 0.05 düzeyde istatistikî olarak önemli farklilik yoktur.

\subsection{Protein oranı (\%)}

Vermikompost uygulamasının atdişi mısır çeşidinde protein oranına ilişkin varyans analiz sonuçları Tablo 6'da verilmiş, yapılan varyans analiz sonucuna göre protein oranı bakımından uygulamalar arasında istastiki olarak \%1 düzeyinde önemli farklılık bulunmuştur. Protein oranı en yüksek $1500 \mathrm{~kg}$ $\mathrm{da}^{-1}$ vermikompost uygulamasında \%8.0 olarak bulunurken, protein oran 1 en düşük kontrol parselinden $\% 7.38$ olarak bulunmuştur. Araştırıcılar, bitki besin elementi oranı ve protein oranının artan solucan gübresi dozuyla doğru orantılı olarak arttığını belirlemişlerdir [38, 39]. Araştırmacıların bulguları sonuçlarımızı destekler niteliktedir. Mısır çeşitleri ile yapılmış olan çalışmalarda protein oranı Kalkan, [40] \% 4.3 ile 4.51, Koca, [41] \% 4.28 ile 4.73 olarak daha düşük değerler gösterirken, Erdal ve ark. [17] \% 7.3-8.7 bulgularımıza yakın değerler elde etmiş̧lerdir.

\subsection{Tane verimi $\left(\mathrm{kg} \mathrm{da}^{-1}\right)$}

Tane verimi bakımından yapılan varyans analiz sonucuna vermikompost uygulamaları arasında istatistiki olarak \%1 düzeyinde önemli farklılık saptanmıştır (Tablo 6). Araştırmada en yüksek tane verimi değeri $750 \mathrm{~kg} \mathrm{da}^{-1}$ vermikompost uygulamasından $1561.26 \mathrm{~kg} \mathrm{da}^{-1}$ olarak bulunurken, en düşük tane verimi ise kontrol parselinden $1193.11 \mathrm{~kg} \mathrm{da}^{-1}$ olarak bulunmuştur (Şekil 1). Kontrol uygulamasından itibaren $750 \mathrm{~kg} \mathrm{da}^{-1}$ seviyelerine kadar tane veriminde artış görülmüştür. Ancak, bundan sonraki seviyelerdeki vermikompost uygulamaları ile $750 \mathrm{~kg} \mathrm{da}^{-1}$ uygulaması ile aynı istatistiki grupta yer almıştır. Vermikompost, toprağın organik madde içeriğini arttırmakta, toprağın havalanmasını sağlamakta, su tutma kapasitesini arttırmakta ve bitki besin maddesi alımını kolaylaştırmakta sonuç olarak verimi olumlu yönde etkilemektedir. Bunun yanı sıra Atiyeh ve ark. [42] solucan gübresinin bitki büyümesini uyarıcı etkisinin, yüksek miktardaki besin kapsamından çok, içeriğindeki yüksek humik madde miktarı ve humus ile ilişkili olan bir 'hormonal etki' den kaynaklandığını açıklamışlardır. Tomati ve ark [43], ise sitokinin, giberellin ve oksin benzeri bileşiklerin solucanlar tarafından salgılandığını belirtmiş̧lerdir. Araştırmacıların tespitlerine paralel olarak, bu çalışmada vermikompost uygulamalarının mısır bitkisinin tane verimine olumlu etkide bulunduğu saptanmıştır. Durukan ve ark. [32] , Vermikompost uygulamalarının mısır bitkisinin toprak üstü aksamını arttırdığını açıklamışlardır. Prasanna ve ark. [13] yapmış oldukları bir çalışmada mısır bitkisinde çiftlik gübresi, yaprak gübresi, sorgum kalıntıları, kümes gübresi ve solucan gübresinin etkilerini denemişler bu deneme sonucunda en yüksek tane verimini solucan gübresi verilen parselden elde etmişlerdir. Öktem ve ark. [28] , Ashoka ve ark. [44] solucan gübre + kimyasal gübre uygulamasından en yüksek tane verimi aldıklarını belirtmişlerdir. Büyükfiliz [45], en yüksek verimi 800 
$\mathrm{kg} \mathrm{da}^{-1}$ vermikompost uygulamasından elde etttiğini açıklamıştır. Bulgularımız, araştırıcıların tespitleri ile uyum içindedir.

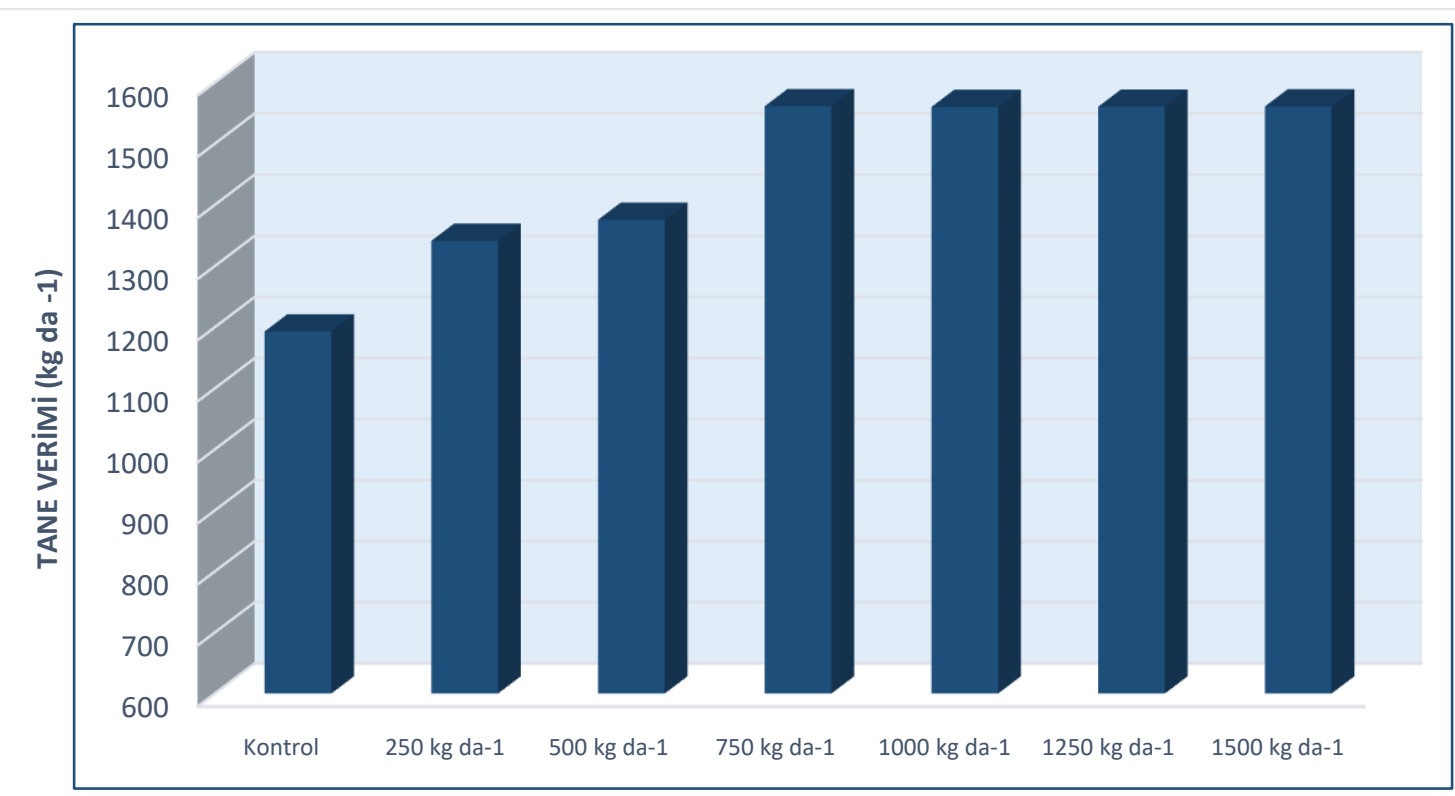

Şekil 1. Vermikompost uygulamalarının tane verimine etkisi

\section{Sonuç ve Öneriler}

Mısır bitkisine farklı miktarlarda uygulanan vermikompost uygulamaları sonucu, tepe püskülü çiçeklenme süresi 54.66 ile 53.33 gün, sap kalınlığ $22.12 \mathrm{~mm}$ ile $24.00 \mathrm{~mm}$, koçanda sıra sayısı 15.86$15.00 \mathrm{sira} /$ koçan, bitki boyu değerleri 209.90 ile $219.90 \mathrm{~cm}$, bitkide yaprak sayısı 12.90 adet/bitki $12.03 \mathrm{adet} / \mathrm{bitki}$, bin tane ağırlı̆ $1359.98 \mathrm{~g}-312.81 \mathrm{~g}$, protein oranı $\% 8-\% 7.38$, koçanda tane ağırlığ $293.1 \mathrm{~g}-254.0 \mathrm{~g}$ ve tane verimi $1561.26 \mathrm{~kg} \mathrm{da}^{-1}-1193.11 \mathrm{~kg} \mathrm{da}^{-1}$ arasında bulunmuştur. Tepe püskülü çiçeklenme süresi ve sap kalınlığı hariç, incelenen diğer özellikler vermikompost uygulanmasından olumlu etkilenmiş, en yüksek tane verimi değeri $750 \mathrm{~kg} / \mathrm{da}$ vermikompost uygulanmasından (1561.26 $\mathrm{kg} \mathrm{da}^{-1}$ ) elde edilmiştir. Ayrıca $750 \mathrm{~kg} \mathrm{da}^{-1} \mathrm{VK}$ uygulamasının kontrol uygulamasına göre daha ekonomik olduğu da saptanmıştır. Çalışma sonucunda vermikompostun tarımın sürdürülebilirliliği açısından uygulanabilir olduğu, ancak daha kapsamlı çalışmaların da yapılmasının da gerekli olduğu düşünülmektedir.

\section{Teşekkür}

Bu çalışma, Doç. Dr. Ayşe Gülgün ÖKTEM danışmanlığında, Muhammed Reşit ÖZEL’in yükssek lisans çalışmasının bir bölümü olup, Harran Üniversitesi, Bilimsel Araştırma Projeleri Koordinasyon Birimi'nce K19160 kodlu proje ile desteklenmiştir.

\section{Yazarların Katkısı}

A.G. ÖKTEM araştırmayı planlamış, denemeyi kurmuş, istatistiki analizleri yapmış, makaleyi yazmıştır. M.R. ÖZEL gözlem ve ölçümleri almıştır.

\section{Çıkar Çatışmasıı Beyanı}

Yazarlar arasında herhangi bir çıkar çatışması bulunmamaktadır. 


\section{Araştırma ve Yayın Etiği Beyanı}

Yapılan çalışmada araştırma ve yayın etiğine uyulmuştur.

\section{Kaynaklar}

[1] Anonymous. 2019. FAO (Food and Agriculture Organization of the United Nations) Statistics http://www.fao.org/faostat (Erişim tarihi: 15.04.2021)

[2] Anonymous. 2019. National Agriculture Statistics Service https://www.nass.usda.gov/ (Erişim tarihi: 20.04.2021).

[3] Aygün Y., Acar M. 2004. Organik gübreler ve önemi. Hasat Dergisi, 228: 68-72.

[4] Demir H., Polat E., Sönmez İ. 2010. Ülkemiz için yeni bir organik gübre: solucan gübresi. Tarım Aktüel 14: 54-60.

[5] Maltaş A.Ş., Tavalı İ.E., Uz İ, Kaplan M. 2017. Kırmızı baş lahana (Brassica oleracea var. capitata f. rubra) yetiştiriciliğinde vermikompost uygulaması. Mediterranean Agricultural Sciences, 30: 155-161.

[6] Alam M.N., Jahan M.S., Ali M.K., Ashraf M.A., Islam M.K. 2007. Effect of vermicompost and chemical fertilizers on growth, yield and yield components of potato in barind soils of Bangladesh. Journal of Application Science Research 3 (12): 1879-1888.

[7] Ali M., Griffiths A.J., Williams K.P., Jones D.L. 2007. Evaluating the growth charecteristics of lettuce in vermicompost and green waste compost. European Journal of Soil Biology 43: 316319.

[8] Singh R., Sharma R.R., Kumar S., Gupta R.K., Patil R.T. 2008. Vermicompost substitution influences growth, physioligical disorders, fruit yield and quality of stawberry (Fragaria $\mathrm{x}$ ananassa duch). Bioresource Technology, 99: 8507-8511.

[9] Rangarajan A., Leonard B., Jack A. 2008. Cabbage Transplant Production Using Organic Media on Farm. In: Proceedings of National Seminar on Sustainable Environment, Edited by N. Sukumaran, Bharathiar University Pres., Coimbatore, 45-53.

[10] Çıtak S., Sönmez S., Koçak F., Yasin S. 2011. Vermikompost ve ahır gübresi uygulamalarının 1spanak bitkisinin gelişimi ve toprak verimliliği üzerine etkileri. Batı Akdeniz Tarımsal Araştırma Enstitüsü Derim Dergisi, 28 (1): 56-69.

[11] Ferreira M.E., Cruz M.C.P., Da Cruz M.C.P. 1992. Effects of compost from municipal wastes digested by earthwarms on the dry matter production of maize and soilproperties. Cientifica Japoticabol, 20 (1): 217-226.

[12] Jat R.S., Ahlawat I.P.S. 2006. Direct and residual effect of vermicompost, biofertilizers phophorus on soil nutrient dynamics and productivity of chickpea-fodder maize. Journal of Sustainable Agriculture 28: 41-54.

[13] Prasanna K., Halepyati A.S., Desai B.K., Pujari B.T. 2007. Effect of integrated nutrient management on the productivity and nutrient uptake by maize (Zea mays L.). Karnataka Journal of Agricultural Sciences 20 (4): 833-834.

[14] Anonim, 2017. Şanlıurfa Meteoroloji Bölge Müdürlüğü kayıtları, Şanlıurfa.

[15] İdikut, L., Kara, S.N. 2013. Tane ürünü için yetiştirilen ikinci ürün mısır çeşitlerinin bazı verim öğeleri ile tane nişasta oranlarının belirlenmesi. KSÜ Doğa Bilimleri Dergisi 16 (1): 8-15.

[16] Öktem A., Toprak A. 2013. Çukurova koşullarında bazı atdişi mısır (Zea mays L. indentata) genotiplerinin verim ve morfolojik özelliklerinin belirlenmesi. Harran Üniversitesi Ziraat Fakültesi Dergisi, 2013, 17(4): 15-24.

[17] Erdal Ş., Pamukçu M., Ekiz H., Soysal M., Savur O., Toros A. 2009. Bazı silajlık mısır çeşit adaylarının silajlık verim ve kalite özelliklerinin belirlenmesi. Akdeniz Üniversitesi Ziraat Fakültesi Dergisi, 22: 75.81.

[18] Üzen S. 2020. Şanlıurfa Koşullarında Bazı Atdişi Mısır (Zea mays L. indentata) Genotiplerinin Verim ve Verim Unsurlarının Belirlenmesi. Yüksek Lisans Tezi, Harran Üniversitesi, Fen Bilimleri Enstitüsü, Şanlıurfa, 1-87.

[19] Bakış B., 2018. Mardin Ekolojik Koşullarında II. Ürün Olarak Yetiştirilen Bazı Tanelik Mısır (Zea mays L. indentata) Çeşitlerinin Verim ve Bazı Verim Unsurlarının Belirlenmesi. Yüksek Lisans Tezi, Siirt Üniversitesi, Fen Bilimleri Enstitüsü, Siirt, 1-87. 
[20] Demiray Y.G., Kılıç H. 2015. Bingöl Ekolojik Şartlarına Uygun Tane Mısır (Zea mays L.) Çeşitlerinin Belirlenmesi. 11. Tarla Bitkileri Kongresi. Kongre kitabı, 7-10 Eylül, Çanakkale, 255-258.

[21] Babaoğlu M., 2003. Farklı Kökenli Mısır (Zea mays L.) Genotiplerinin Çeşitli Agronomik ve Kalite karakterleri bakımından Karşılaştırmalı Olarak Değerlendirilmesi. Doktora Tezi. Trakya Üniversitesi, Fen Bilimleri Enstitüsü, Edirne, 1-108.

[22] Şekeroğlu N., Dede Ö., Deveci M., Kara Ş.M. 2000. Melez mısır populasyonlarında verim ve verim unsurları arasındaki ilişkilerin path analizi ile belirlenmesi. Gazi Osman Paşa Üniversitesi Ziraat Fakültesi Dergisi, 17 (1): 79-82.

[23] Vartanlı S. 2006. Ankara Koşullarında Hibrit Mısır Çeşitlerinin Verim ve Kalite Özelliklerinin Belirlenmesi. Yüksek Lisans Tezi. Ankara Üniversitesi Fen Bilimleri Enstitüsü, 1-80.

[24] Yılmaz N., Han E. 2016. Giresun ekolojik koşullarında bazı mısır çeşitlerinin tane verimi ve verim ögelerinin belirlenmesi. Iğdır Üniversitesi Fen Bilimleri Enstitüsü Dergisi, 6 (3): 171-176.

[25] Turgut İ. 1998. Bursa koşullarında bazı melez mısır (Zea mays indentata Sturt.) çeşitlerinde tane verimi ve bazı verim öğelerinin korelasyonu ve path analizi. Uludağ Üniversitesi Ziraat Fakültesi Dergisi 14: 173-182.

[26] Müftüoğlu N.M., 2016. Vermikompostun 1spanak verimi ve bazı toprak özellikleri üzerine etkisi. Çanakkale 18 Mart Üniversitesi Ziraat Fakültesi Dergisi, 4: 1-5.

[27] Özkan N., Dağlığlu M., Ünser E., Müftüoğlu N.M. 2016. Vermikompostun 1spanak (Spinacia oleracea L.) verimi ve bazı toprak özellikleri üzerine etkisi. Çanakkale 18 Mart Üniversitesi Ziraat Fakültesi Dergisi, 4 (1): 1-5.

[28] Öktem A.G., Öktem A., Yahlizade B. 2018. Misır bitkisinde (Zea mays L. indentata) vermikompost uygulamaları. Ivpe Yayınları, Karadağ, 1: 355-367.

[29] Oo A.N., Iwai C.B., Saenjan P. 2015. Soil properties and maize growth in saline and non-saline soils using cassava-industrial waste compost and vermicompost with or without earthworm. Land Degradation and Development, 26: 300-310.

[30] Ateş, 2016. Endojeik Toprak Solucanının Mısır Bitkisinde Besin Elementi Alımına Etkisi. Yüksek Lisans Tezi. Süleyman Demirel Üniversitesi, Fen Bilimleri Enstitüsü, Isparta, 1-57.

[31] Özkan N, Müftüoğlu N.M. 2015. Farklı Dozlardaki Vermikompostun Marul Verimi ve Bazı Toprak Özellikleri Üzerine Etkisi. VII. Ulusal Bahçe Bitkileri Kongresi, 25-28 Ağustos, Çanakkale, 121-124.

[32] Durukan H., Saraç H., Demirbaş A. 2020. Farklı dozlarda vermikompost uygulamasının mısır bitkisinin verimine ve besin elementleri alımına etkisi. Ziraat Fakültesi Dergisi, Özel Sayı: 45-51.

[33] Köksal S.B., Aksu G., Altay H. 2017. Vermikompostun bazı toprak özellikleri ve pazı bitkisinde verim üzerine etkisi. Çanakkale 18 Mart Üniversitesi Ziraat Fakültesi Dergisi, 5 (2): 123-128.

[34] Peyvast G.H., Olfati J.A., Madeni S., Forghani A. 2007. Effect of vermicompost on the growth and yield of spinach (Spinacia oleracea L.). Journal of Food, Agriculture \& Environment 6: 132 135.

[35] Taş T. 2020. Şanlıurfa koşullarında bazı atdişi hibrit mısır (Zea mays indentata Sturt) çeşitlerinin tane özellikleri ile tane verimi arasındaki ilişkilerin belirlenmesi. ISPEC Tarım Bilimleri Dergisi, 4: 222-233.

[36] Aygün İ. 2012. Mısırda Aynı Genetik Tabandan Gelen Tek Melez, Üçlü Melez ve Çift Melezlerde Tane Verim ve Bazı Agronomik Özelliklerin Karşılaştırılması. Yüksek Lisans Tezi, Selçuk Üniversitesi, Fen Bilimleri Enstitüsü, Konya, 1-182.

[37] Kuşvuran A., Nazlı R.İ. 2014. Orta Kızılırmak havzası ekolojik koşullarında bazı mısır (Zea mays L.) çeşitlerinin tane mısır özelliklerinin belirlenmesi. Yüzüncü Yıl Üniversitesi Tarım Bilimleri Dergisi, 24 (3): 233-240.

[38] Küçükyumuk Z., Gültekin M., Erdal İ. 2014. Vermikompost ve mikorizanın biber bitkisinin gelişimi ile mineral beslenmesi üzerine etkisi. Süleyman Demirel Üniversitesi Ziraat Fakültesi Dergisi, 9 (1): 51-58.

[39] Tavalı İ.E., Uz İ., Orman Ş. 2014. Vermikompost ve tavuk gübresinin yazlık kabağın (Cucurbita pepo L. cv. Sakız) verim ve kalitesi ile toprağın bazı kimyasal özellikleri üzerine etkileri. Akdeniz Üniversitesi Ziraat Fakültesi Dergisi, 27 (2): 119-124. 
[40] Kalkan M, 2008. Farklı Misır Olum Grupları ve Hasat Tarihlerinde Verim, Verim Öğeleri İle Besin Değerleri ve Aflatoksin Düzeylerinin Belirlenmesi. Yüksek Lisans Tezi, Selçuk Üniversitesi Fen Bilimleri Enstitüsü, Konya, 1-88.

[41] Koca Y.O. 2009. Aydın Bölgesinde, Birinci ve İkinci Ürün Misırda (Zea mays L.) Verim, Verim Öğeleri, Fizyolojik ve Diğer Bazı Özellikler Arasındaki Farklılıklar. Doktora Tezi, Adnan Menderes Üniversitesi, Fen Bilimleri Enstitüsü, Aydın, 1-135.

[42] Atiyeh R.M., Edward C.A., Arancon N.Q., Metzger J.D. 2002. The influence of humic acids derived from earthworm-processed organic wastes on plant growth, Bioresource Technology, 84 :(1) 7-14.

[43] Tomati V., Grappelli A., Galli E. 1988. The hormone like effect of earthworm casts on plant growth. Biology and Fertility of Soils, 5: 288-294.

[44] Ashoka P., Anand S.R., Mudalagiriyappa P., Smitha R. 2009. Effect of macro and micronutrients with organics on growth, quality, yield and economics of baby corn (Zea mays L.) in tungabhadra command area. Crop Research (Hisar) 37: 15-18.

[45] Büyükfiliz F. 2016. Vermikompost Gübrelemesinin Ayçiçeği (Helianthus annus L.) Bitkisinin Verim ve Bazı kalite Parametreleri Üzerine Etkisi. Yüksek Lisans Tezi, Namık Kemal Üniversitesi, Fen Bilimleri Enstitüsü, Tekirdağ, 1-62. 